\title{
General Observation Domain
}

National Cancer Institute

\section{Source}

National Cancer Institute. General Observation Domain. NCI Thesaurus. Code C154639.

Standardized qualitative and quantitative general observations about a patient. 